\title{
En ti år gammel pike med svimmelhet
}

\author{
Svimmelhet er et uspesifikt symptom ved en rekke sykdommer. \\ Det er også en hyppig bivirkning ved legemiddelbruk. Svimmelhet \\ hos barn er derimot sjelden årsak til at foreldre bringer barnet til lege. \\ I denne presentasjonen handler det om en vanlig type svimmelhet \\ i en uvanlig aldersgruppe.
}

Se kommentar side 635 og kunnskapsprøve på www.tidsskriftet.no/quiz
En tiår gammel pike kom henvist til øre-nesehals-lege pga. svimmelhet. Hun møtte til undersøkelse fulgt av moren. Pasienten hadde da hatt anfallsvis svimmelhet $i$ nærmere en måned. Hovedsymptomet var stillingsutløst opplevelse av spinning (gyrasjon) med varighet 10-30 sekunder, og dette presenterte seg særlig når hun la seg i sengen om kvelden. Anfallene var ledsaget av uvelfølelse, kvalme og engstelse. Det var ingen bevissthetsforstyrrelse i forbindelse med anfallene. Det var ikke opplysning om hodetraume i sykehistorien. Piken hadde tidligere hatt hodepineplager, og det var nære slektninger som hadde migrene. Pasienten hadde imidlertid ikke hatt migreneanfall i tilslutning til svimmelhetsanfallene. Mellom anfallene, som kunne være flere daglige, var hun helt symptomfri.

Svimmelhet er en relativt sjelden årsak til at barn og unge søker lege. Bare $0,7 \%$ av barn som oppsøkte et sykehus i Finland, hadde svimmelhet som symptom (1). I en annen screeningstudie av ca. 1000 barn hadde ca. $8 \%$ opplevd svimmelhet, hvorav $23 \%$ ( $2 \%$ av totalen) i en grad som påvirket den daglige aktiviteten i kortere eller lengre tid (2). Dette samsvarer med en annen epidemiologisk studie av 2169 pasienter med svimmelhet der 48 (2,2\%) var barn (3). Vår erfaring fikk vi ved vår balanseklinikk totalt henvist ca. 2000 nye pasienter med diagnose svimmelhet/balanseproblemer. Av disse var kun 40 pasienter $(2 \%)$ i alderen $5-15$ år.

Pasienten gjennomgikk standard utredningsprosedyre med nøye anamnese lutløsende faktorer, anfallshyppighet, anfallstype, varighet av anfall, anfallsfrekvens, ledsagende symptomer) og generell øre-nesehals-status med otonevrologisk unders $\emptyset$ kelse. Hun fikk utført videonystagmoskopi og videonystagmografi med kalorisk test. Begge disse undersøkelsene ble gjennomført ved første konsultasjon. Testing av balansefunksjonen på plattform (posturografi) er den samme. I løpet av to år (2005-06) ble også utført. MR-undersøkelse av hjernen ble gjort i forløpet av utredningen.

Utredning av barn med svimmelhet fraviker ikke mye fra det som gjøres hos voksne pasienter med svimmelhet. Anamnesen er her, som så ofte i medisinen, svært viktig. F.eks. vil opplysning om hvorvidt et svimmelhetsanfall er stillings- eller bevegelsesutløst være viktig i differensialdiagnostikken mellom sentrale og perifere balanseforstyrrelser.

Ved innføring av videonystagmoskopi som standardprosedyre i utredning av svimmelhet, ble vestibularisdiagnostikken løftet dramatisk. Metoden baserer seg på infrarød teknologi der spesielle videokameraer kan «se» i mørket. Ved videonystagmoskopi er de infrarøde kameraene plassert $i$ en maske (fig 1). Metoden gjør at ufrivillige øyebevegelser (f.eks. nystagmus) kan ses på en TV- skjerm uavhengig av pasientens stilling eller bevegelser. Den eneste forutsetningen er at pasienten er i stand til å holde øynene åpne.

Ved kalorisk testing spyles varmt vann $\left(44^{\circ} \mathrm{C}\right)$ og kaldt vann $\left(30^{\circ} \mathrm{C}\right)$ i øregangen. Dette utløser bevegelse av endolymfen i buegangene som igjen endrer nerveimpulstrafikken i n. vestibularis. Den påfølgende nystagmus (ufrivillige øyebevegelser) kan registereres kvantitativt som mål for funksjonen i det perifere vestibularisapparatet.

Ved undersøkelsen av den ti år gamle piken ble det gjort normale funn ved øre-nesehals-status og otonevrologisk status. Ved videonystagmoskopi ble det ikke observert spontannystagmus, men ved stillingsendring fremkom patologisk nystagmus. I høyre sideleie ble det funnet høyrerettet (geotrop), horisontal nystagmus med varighet ca. 30 sekunder. I venstre sideleie fant man venstrerettet (geotrop), horisontal nystagmus, noe svakere og noe kortere varighet, sammenliknet med høyre side. Pasienten anga svimmelhetsfølelse særlig når hun ble lagt ned på høyre side, men ble også noe svimmel ved dreining mot venstre. Det var ingen tegn til rotasjonskomponent i nystagmusmønsteret, og balansefunksjonen ble vurdert som normal ved posturografi. Ved gjentatte undersøkelser forsvant gradvis nystagmusmønsteret.

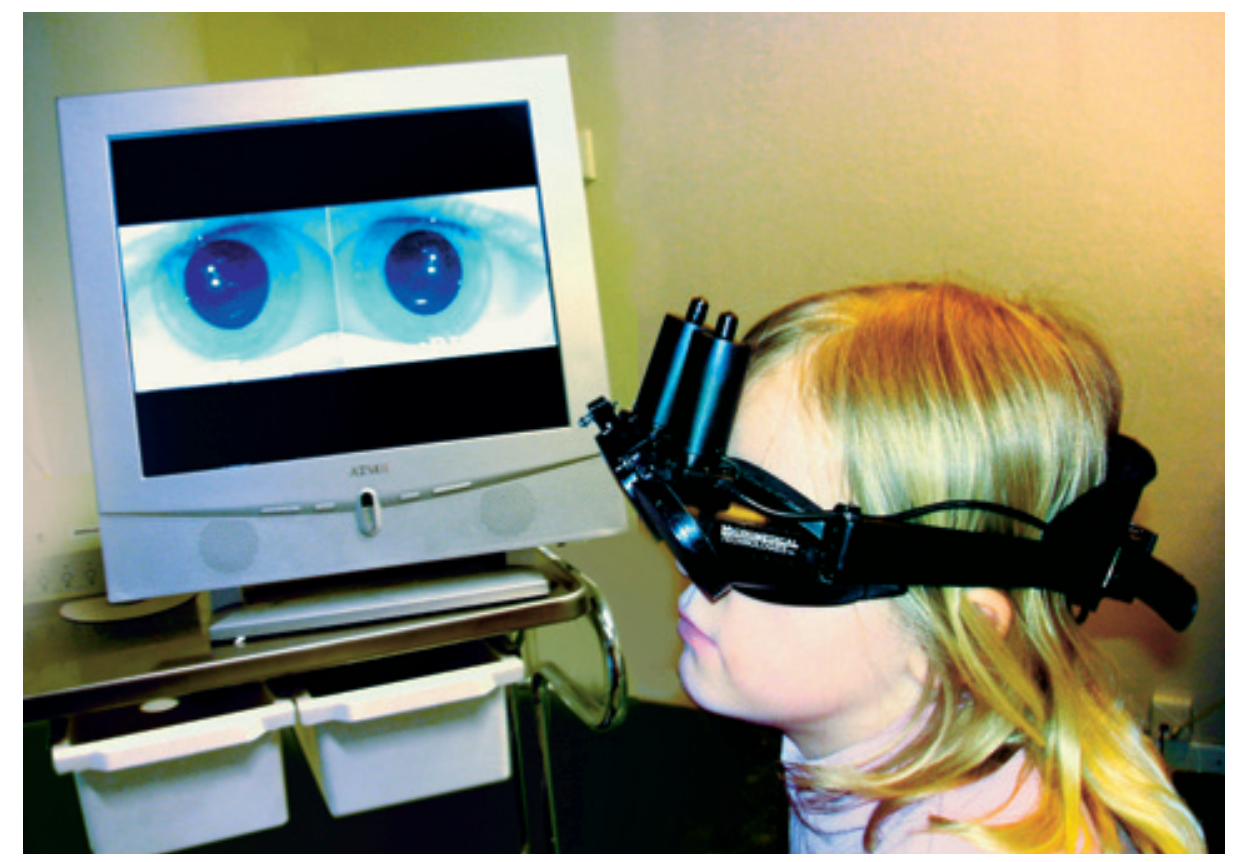

Figur 1 Ved videonystagmoskopi benyttes videobrille og dataskjerm. Illustrasjonsfoto Iseks år gammel pike) 
Ved å avlese nystagmusmønsteret kan man oftest avgjøre om årsaken til svimmelheten er lokalisert sentralt i sentralnervesystemet eller perifert i det indre øret, sågar på hvilken side og hvilken buegang som er affisert. For at nystagmusmønsteret skal kunne identifiseres med nødvendig nøyaktighet og detaljrikdom, er man avhengig av enten videonystagmoskopi eller elektronystagmografi. Med dagens teknologi, tilgjengelig til en overkommelig pris, er videonystagmoskopi å foretrekke. Dette bør finnes på enhver øre-nese-hals-avdeling og nevrologisk avdeling, og hos praktiserende spesialister som ser svimle pasienter regelmessig.

Ut fra sykehistorie og funn konkluderte vi med at denne ti år gamle piken hadde benign paroksysmal posisjonsvertigo. Videonystagmoskopifunnene pekte mot affeksjon av høyre laterale buegang. Tilstanden behandles med reposisjonsmanøver på en måte som gjør at de løse partiklene bringes fra buegangen til utriculus. Manøveren kalles «barbecue-rotasjon» basert på assosiasjonen til rotasjonen av grillspydet. Etter kun én enkelt behandling (barbecue-rotasjon fra høyre mot venstre $360^{\circ}$ ) forsvant pasientens svimmelhetsplager.

\section{Diskusjon}

Svimmelhet hos barn er hyppigst forårsaket av en migreneekvivalent kalt godartet an- fallssvimmelhet hos barn (benign paroxysmal vertigo of childhood) (2). Andre årsaker er infeksjoner i mellomøre og indre øre samt hodeskader (4). Enkelte tilfeller av svimmelhet hos barn skyldes sykdom i sentralnervesystemet (4).

Benign paroksysmal posisjonsvertigo hos barn hevdes å være svært sjeldent (2). Noen eksperter på svimmelhet vil hevde at denne tilstanden ikke finnes hos barn og unge under 15 år. Vi er enig i at svimmelhet generelt er et symptom som sjelden bringer barn og unge til lege, og vi er også enig i at benign paroksysmal posisjonsvertigo sjelden diagnostiseres hos barn. Derimot tror vi ikke at tilstanden er så sjelden hos barn som mange eksperter hevder. Vi tror at løsning av otolitter fra macula utriculi skjer hos barn og unge, og at partiklene kan komme ut i buegangene og forårsake stillingsutløste vertigoanfall på samme måte som hos voksne. Vi får støtte for en slik teori fra funn gjort ved tinningbeinsstudier av barn der man har funnet avleiringer av otolittliknende materiale $\mathrm{i}$ cupula (5). Årsaken til at barn og unge så sjelden kommer til legen med svimmelhetsanfall tror vi henger sammen med at disse barna i stor grad «selvreponerer» seg gjennom sitt bevegelsesmønster i lek og aktivitet. Både Epleys manøver (behandlingsprosedyre ved benign paroksysmal posisjonsvertigo ifra bakre buegang) og barbecuemanøver er bevegelsesmønstre som barn ofte spontant gjennomfører under lek (ruller seg rundt, stuper kråke, hopper og spretter, løper og faller).

\section{Olav Skatvedt \\ Ullensaker Øre-Nese-Hals}

\section{Svein Mjøen}

sveimjo@online.no

Alan Sealy

Klinikk for Alle

Gardeveien 17

0363 Oslo

Oppgitte interessekonflikter: Ingen

\section{Litteratur}

1. Riina N, Ilmari P, Kentala E. Vertigo and imbalance in children: a retrospective study in Helsinki University otorhinolaryngology clinic. Arch Otolaryngol Head Neck Surg 2005; 131: 996-1000.

2. Niemensivu R, Pyykko I, Wiener-Vacher SR et al. Vertigo and balance problems in children - an epidemiologic study in Finland. Int J Pediatr Otorhinolaryngol 2006; 70: 259-65.

3. Yin M, Ishikawa $\mathrm{K}$, Wong WH et al. A clinical epidemiological study in 2169 patients with vertigo. Auris Nasus Larynx 2008; doi: 10.1016/j.anl.2008.03.006.

4. Kitsko DJ, Dohar JE. Inner ear and facial nerve complications of acute otitis media, including vertigo. Curr Allergy Asthma Rep 2007; 7: 444-50.

5. Bacor E, Wright CG, Karmody CS. The incidence and distribution of copular deposits in the pediatric vestibular labyrinth. Laryngoscope 2002; 112: 147-51.

Manuskriptet ble mottatt 12.3. 2008 og godkjent 28.8. 2008. Medisinsk redaktør Odd Terje Brustugun.

\section{Kommentar}

\section{Barn og vertigo}

Det foreligger flere rapporter om erfaringer med vertigo hos barn (1-3). Det synes å være gjennomgående at omkring halvparten av barna får migrenediagnoser, inkludert det som i den internasjonale migreneklassifikasjonen kalles «benign paroxysmal vertigo of childhood» (4) og arvelig episodisk ataksi. De øvrige fordeler seg på en lang rekke ulike diagnoser innenfor ulike spesialiteter. Sentralt i utredningen er en grundig anamnese og klinisk undersøkelse samt, når det er nødvendig, et tverrfaglig samarbeid.

Øre-nese-hals-legens tilnærming er skissert $\mathrm{i}$ tabell 1. En god rutine, gjerne med bruk av strukturert anamneseopptak, og trening på riktig undersøkelsesteknikk er avgjørende. Det er viktig å undersøke pasientene $\mathrm{i}$ akuttfasen så langt det er mulig, både for å avsløre eventuelle alvorlige sykdommer og for å dokumentere objektive funn som senere har en tendens til å forsvinne. Den beste måten å lære seg teknikkene på, er å undersøke flest mulig vertigopasienter i akuttfasen. Det er også viktig å sette av nok tid til disse pasientene.

Tabell 1 Diagnostikk av vestibulær vertigo

\begin{tabular}{|c|c|}
\hline \multirow[t]{5}{*}{ Anamnese } & $\begin{array}{l}\text { Debut } \\
\text { Akutt, gradvis, traume, infeksjon, påkjenninger }\end{array}$ \\
\hline & $\begin{array}{l}\text { Tidsforløp } \\
\text { Anfall, varighet, hyppighet, konstant, progrediering, bedring }\end{array}$ \\
\hline & $\begin{array}{l}\text { Ledsagende symptomer } \\
\text { Otalgi, hodepine, kvalme, brekninger, hørselstap, tinnitus, lysskyhet, } \\
\text { lydskyhet, synsforstyrrelser, falltendens, bevissthetstap, nevrologiske } \\
\text { symptomer }\end{array}$ \\
\hline & $\begin{array}{l}\text { Utløsende faktorer } \\
\text { Hodebevegelser, lyder, trykkendringer, menstruasjon, stress, søvnunder- } \\
\text { skudd, matvarer, synsinntrykk, bruk av synet til arbeid, lekser, gymna- } \\
\text { stikk }\end{array}$ \\
\hline & $\begin{array}{l}\text { Svimmelhetens karakter } \\
\text { Vertigo, nautisk, rotatorisk, bevegelsesforstyrrelse, ustøhet, vegetative } \\
\text { symptomer, nærsynkope }\end{array}$ \\
\hline \multirow[t]{5}{*}{ Klinisk undersøkelse } & $\emptyset$ re-nese-hals-status \\
\hline & Hjernenerver \\
\hline & $\begin{array}{l}\text { Balanse og koordinasjon } \\
\text { Gange på linje, Rombergs prøve, skjerpet Rombergs prøve, steptest, } \\
\text { finger-nese-prøve, diadokokinesi }\end{array}$ \\
\hline & $\begin{array}{l}\text { Nystagmusundersøkelser } \\
\text { Primærposisjon, sideblikk, hoderistingstest, Dix-Hallpikes manøver }\end{array}$ \\
\hline & $\begin{array}{l}\text { Hodeimpulstest } \\
\text { En undersøkelse av den vestibulookulære refleks som påviser ensidig } \\
\text { utfall ved at pasienten ikke klarer å holde blikket fiksert ved raske, } \\
\text { passive hodebevegelser mot den paretiske siden }\end{array}$ \\
\hline
\end{tabular}

